\title{
Omani School Students' Knowledge, Attitudes and Behaviors Towards Date palms: Investigating the Role of Gender and Geographical Regions
}

\author{
Khalsa Alaiwi ${ }^{1}$, Abdullah Ambusaidi ${ }^{2 *}$ \\ 1 Biology teacher, Ministry of Education, OMAN \\ 2 Humanities Research Centre, Sultan Qaboos University, OMAN
}

Received 28 April $2020 \cdot$ Accepted 28 August 2020

\begin{abstract}
The date palm occupies a special place in the Arab cultural heritage in general, and the Omani heritage in particular. The development of the agricultural sector and date palms cultivation depend mainly on the human factor represented by the farmlands with scientific skills and knowledge. This study explores Omani school students' knowledge, attitudes, and behaviors towards date palms in light of two variables: gender and geographical area. The research follows a descriptive method, where a questionnaire consisting of 50 phrases about the date palms was distributed ( 25 knowledge, 15 attitudes, and 10 behaviors). The sample consisted of 894 students (447 males and 447 females) randomly selected from different schools in two geographically different governorates or regions (Muscat and Dakhiliya). The results showed a lack in students' knowledge of date palms, while they showed positive attitudes and behaviors. Knowledge about date palms among male and female students is the same, but attitudes and behaviors are more positive with male students than female students. In addition, students who live in Al-Dakhiliya (Interior) Governorate have more favorable attitudes and behaviors than those living in Muscat Governorate. The results also showed statistically significant differences at $(\alpha=0.05)$ in the students' attitudes and behaviors on the date palms due to the existence of date palms in their homes or a family member working in the agricultural field. This study highlights the importance of developing a strategic plan to generate interest in date palms among school students across Oman.
\end{abstract}

Keywords: date palms, tenth grade students, knowledge, attitudes, behaviors

\section{INTRODUCTION}

The date palm occupies a unique and distinctive place in the Arab cultural heritage, and no tree in the history of human civilization has received the same attention that the palm has received. It permeates all daily lives of people, as it is in his food, drink, habitation, and work. God Almighty also has exalted the value of the date palm in more than twenty verses, describing it as a blessed tree, and placed it in a unique position among other trees. The palm tree was and will remain the secret of life and creativity in Omani cultural values. It was mentioned at different levels in Omani literature, and many Omani poets and writers sang it and mentioned in poetry debates that prefer a variety of palm trees over another variety. The palm tree also had a great place in popular proverbs and Omani rule and contributed to the inheritance of customs and traditions between generations (Al-Hashemi, 2003). The date palm has been and will remain a symbol of life and creativity in the Omani culture. It has been mentioned profusely in Omani literature by poets and writers. It is also found in Omani popular sayings and proverbs and thus contributed to the passing on of customs and traditions from one generation to another (Al-Hashemi, 2003).

The date palm tree has traditionally formed an essential element in the Omani people, as it is the tree they most interact with in daily life, social customs, and traditions. The date palm is one of the most widespread local trees in the Sultanate of Oman, covering large areas and decorating streets and homes, due to its suitability to the country's hot climate and shortage of water for 


\section{Contribution to the literature}

- Students' knowledge, attitudes and behaviors have an effects on their practice of an agriculture related activities.

- The research results showed that there is a gender difference between male and female students in their attitudes and behaviors about date palm trees but no such differences in the knowledge.

- The place where students live, the existence of date palms in their homes and if family member works in the agricultural field all have an effects on students' knowledge, attitudes and behaviors.

long periods. Also, the date palm can decrease the atmospheric temperature and the level of pollution resulting from industrial activities (Ibrahim,2010). It is estimated that there are about 7.56 million date palms in the Sultanate of Oman, in a total area of about 36 thousand hectares, and produces approximately 369 thousand tons (Ministry of Agriculture and Fisheries, 2020). Work is also underway on the project of planting a million date palms by the directives of the late His Majesty Sultan Qaboos bin Saeed, which is a testimony to the importance of the date palm to the Omani people and heritage. The project ensures the date palm will remain as the backbone of food security in Oman and the date's industry will be continued on by generations to come. His Majesty stressed the importance of the date palm by saying, "...after looking into food affairs in our country, we found that the date palm, since ancient times, is the backbone of food security in Oman" (Badawi et el., 2016). Despite the great importance of date palms, unfortunately the school curricula do not highlight the fact that these trees have been and are the main source of food security, and they represent cultural and social symbols to Omani people.

Considering this importance in interest in the date palm, it is necessary to pay attention to student's knowledge, attitudes, and behaviors towards it. Increasing students' agricultural knowledge leads to improving their farming practices and developing positive attitudes towards agriculture through their involvement in experiential learning and activities (Ambusaidi, Al-Yahyai, \& Taylor, 2015). This includes the cultivation and care of date palms and all practices associated with it. The interest in environmental knowledge in a practical way provides students with the opportunity to learn more about the mechanism of fruit cultivation, including date palms. That interest will enrich the academic curricula, enhance educational and personal development (Astin, 1993; Christian, Evans, Conner, Ransley, \& Cade, 2012), increase students' knowledge of current global food issues, including the importance of using natural resources in a sustainable manner (Bowker \& Tearle, 2007). Consequently, this will motivate students and adjust their perceptions and knowledge toward agriculture (Bowker \& Tearle, 2007; Hutchinson et al., 2015).

Students' learning through cultivation, whether planting date palms or other trees and caring for them outside the classroom, allows the learner to obtain learning experiences that are difficult to obtain in the typical classroom (Ghazi, 2000) and promotes critical thinking, practical training and cooperative learning (Davidson, 2014). For this reason, the Sultanate of Oman's interest in harvesting in schools, especially palm cultivation, comes to expand the agricultural area and direct the attention of students to the date palm as a vital resource for them and for future generations and at the same time achieving the goals of sustainable development in the school environment. Some schools in the Sultanate have started undertaking projects related to the date palm, including one boys' school called AlFadhil Bin Al-Abbas, which is located in the south of Al Batinah Governorate. The school's project concept was to plant date palms in the school's garden and each date palm was named after a student. Each student follows up his date palm in terms of watering and care. Each student looks after his date palm during his study at the school. This project trains students to practice date palm related work and helps them acquire the skills in agriculture as a way to promote the values of productive work and taking individual and collective responsibility (Al-Majrafi, 2019).

A group of researchers considers the importance of knowing the student's attitude and goals towards his environment (Tal, Alon, \& Morag, 2014) and assisting him in developing positive attitudes towards agriculture in general and local tree cultivation (Osborne, Simon, \& Collins, 2003). Passy et al. (2011) found that students who participated in school gardening activities gained a positive attitude towards healthy, nutritious food, and they developed good habits to incorporate vegetables into their diet. In addition, they increased their scientific knowledge and their skills in reading, writing, and numeracy. Self-confidence was another positive effect of engaging in agricultural activities (Hoffman et al., 2004; Sheffield, 1992), as well as positively influencing young people's behaviors and attitudes towards consuming vegetables and fruits (Heim et al., 2009; Ohly et al., 2016; Williams \& Dixon, 2013).

Therefore, interest in palms and local trees may lead to the development of positive agricultural attitudes among students. This is what educators seek because that leads to maintaining the continuity of the learning effect and applying the curriculum, which in turn leads to good academic performance, especially in science and 
geography, and increases motivation towards learning and enhancing scientific thinking and creativity (Jones, 2012).

Not only knowledge and attitudes are essential to students, but also there is a need to look at the students' behaviors. Therefore, emphasis must also be placed on student behaviors while dealing with date palms and local trees, as the students' interaction with these trees increases their environmental knowledge and commitment to become an environmentally responsible person (Hutchinson et al., 2015). Through direct engagement with the date palm, students can acquire environmental skills like knowledge of its kinds, behavioral skills such as performing irrigation, and personal skills such as knowledge of healthy foods (Triador, Farmer, Maximova, Willows, \& Kootenay, 2015).

Hence, the decision-makers in the ministry of education and ministry of agriculture should work together to give more emphasis to students' knowledge, behaviors, and attitudes towards the date palm. This may include knowledge of date palms varieties and the methods of cultivating, watering, and caring of the trees, the rising of the date fruits and then carrying out the pollination process, to reaping the fruits and storing them for long periods. Moreover, the heritage aspect of the date palms should overlook, such as students' knowledge of the industries related to the date palms and traditional songs in the practice of the date palms activities.

By looking at Omani science and social studies textbooks in all grades (1-12), the lack of mentioning the date palms can be clearly noticed especially in science textbooks. Although the science textbooks included a comprehensive explanation about plants, their stages of growth, and their importance in nature, there is no focus on date palms either from the scientific point of view or from its cultural and social aspects and their role in the Omani society. However, the Omani science and social studies teachers are subjected to different training programs pre and in-service to teach several topic including topics related to plants and local agriculture when these topics are included in the curriculum. Some teachers are trying their best to link arouse interest in student's minds about the local agriculture whenever the curricula allow. Nonetheless, it should not be up to teachers to do it voluntarily; it should be well planned and embedded in the curriculum so that every teacher does it.

Hence, this study comes to investigate students' knowledge, attitudes, and behaviors towards the date palms in light of gender and the geographical area. The researchers hope that this study will benefit science teachers, supervisors, and educators and those who develop curricula and workers in the field of agriculture and agricultural research in aspects like students' knowledge, attitudes, and behaviors towards the palm. This may help in creating a generation that is conscious and interested in the date palm and optimizing its investment.

\section{STUDY PROBLEM}

The development of the agricultural sector in general and palm cultivation, in particular, depends mainly on the human factor represented by the farming labor with scientific skills and knowledge, and a motivation to work and take responsibility for raising productivity and improving its quality (Al-Hamiri \& Al-Badri, 2001). Previous researches showed that students' attitudes about agriculture could be changed to become positive by activating agricultural activities using appropriate teaching methods in schools (Ambusaidi \& Al-Saidi, 2019; Metin, Acisli \& Kolomuc, 2012; Ugras et al., 2012).

However, young Omani people nowadays are reluctant to cultivate agriculture, as the oil sector competes with date palms, and people go to the quick, profitable workplace. The National Center for Statistics and Information (NCSI) indicates that approximately 91,349 expatriates work in the agriculture and fishing sector compared to only 1077 Omanis (National Statistics and Information Center (NCSI), 2018). In light of the Sultanate's interests in the date palms through carrying out of a set of projects such as the "Million Date palms Project" and the "Annual Date Festival,". The current study aims to investigate students' knowledge, attitudes, and behaviors towards the date palms in light of two variables: gender and geographical area (region). The new thing about the study is that it is the first research paper done at school level in Oman that deals with students' knowledge, attitudes, and behaviors towards the date palms.

\section{RESEARCH QUESTIONS}

The current study addresses the following four research questions:

1. What are the knowledge, attitudes, and behavior of grade 10 students in Omani schools towards the date palms?

2. Do knowledge, attitudes, and behaviors differ according to gender, geographical distribution, and the interaction between them?

3. Do students' knowledge, attitudes and behaviors towards date palms differ if there are date palms in their house or not?

4. Do students' knowledge, attitudes and behaviors towards date palms differ if a family member works in the agriculture sector? 
Table 1. Distribution of the sample according to the study variables

\begin{tabular}{lccc}
\hline Gender & \multicolumn{2}{c}{ Geographical Region } & Total \\
\cline { 2 - 3 } & Al-Dakhiliyah & Muscat & \\
\hline Male & 220 & 230 & 447 \\
Female & 227 & 217 & 447 \\
Total & 447 & 447 & 894 \\
\hline
\end{tabular}

\section{METHODOLOGY}

\section{Participants}

The sample consisted of 894 school students $(447$ males and 447 females) from Grade 10 . Students at grade 10 have reached a level of mental and social development that enables them to understand the given questions. In addition, the researchers assume that these students may have some experience in the agricultural activities. Students were selected from different schools in two Omani geographical regions (Governorates), using a stratified random sampling method to ensure enough student participants to reflect trends within the two study variables: gender and geographical regions. According to Cohen (2000), stratified random sampling is a useful blend of randomization and categorization, thereby enabling both quantitative and qualitative research to be engaged. The randomization is done in each region to select both the schools and students within schools. From each area, eight schools picked that consist of four male schools and another four female' schools. The number of students varied in each class that led to a variation in the number of males and females in the sample

Concerning regions, 440 students were from AlDakhiliyah Governorate, which is characterized as an interior and dry area thus providing better environment for quality palm date, while 448 student participants were from Muscat Governorate, which is characterized as an urbanized area with less farmland. School locations and density of student populations were taken into consideration when the questionnaire instrument was administered to participants in order to ensure findings reveal a clear picture of students' knowledge, attitudes, and behaviors about date palms that may, over time, improve their knowledge, attitudes, and behaviors. The study instrument was administered at the end of the $2019 / 2020$ academic year by the researchers with the help of school science teachers. Table 1 shows the distribution of the sample according to the two study variables.

\section{The Research Instruments}

The research method used in this study is a surveybased approach based on a questionnaire which was used to measure students' knowledge, attitudes, and behaviors towards date palms. This type of research method was considered most suitable to achieve the purpose of the study. The instrument consisted of three sub-scales: the knowledge, attitudes and behaviors. For students' knowledge sub-scale, the true and false format was used. A three-point Likert scale was used to measure students' attitudes and behaviors towards the date palms. Each item in these two sub-scales featuring the following response choices: 3 = agree, 2 = neutral (undecided), 1 = disagree. For the negative items in the attitudes sub-scale, a revise points were given: 1 = agree, 2 = neutral (undecided), 3 = disagree. Since the study sample was students whose first language is Arabic, the three sub-scales were prepared in Arabic. The items distributed with each sub-scale are as follows: knowledge about date palms (25 items), attitudes towards date palms (15 items), and behaviors about date palms (10 items). The three sub-scales were designed after reviewing the previous literature related to agricultural education, such as Ambusaidi et al. (2018), Ambusaidi, and Al-Alwi (2019), Wang (2007), and Meischen and Trexler, (2003). The final draft of the instrument (three sub-scales) consisted of 50 items. For the validation process (face and content validity), the instrument was given to five specialists in agricultural education. They were asked to give their opinions on:

- The suitability of this instrument in achieving the aims of the study

- Whether instrument items were appropriate to each sub-scale which they belonged to.

- The accuracy of the language used

- Whether or not items needed to be added or omitted

In response to the specialists' opinions, some items and the sub-scale layout were modified to make it easier for students to respond. Most suggested modifications were implemented, such as rewording some items or changing the placement of some items. Regarding the instrument's reliability, the internal consistency coefficient (Cronbach's Alpha) was used. This measure indicated a strong correlation between the elements and the dimensions, which they measure (knowledge, attitudes, and behaviors). The reliability coefficient for the subscale was between $0.70-0.80$, which is considered suitable for the study. After assuring the instrument's reliability and validity, 50 items measuring students' knowledge, attitudes, and behaviors towards date palms were administered to the sample.

\section{Data Analysis}

Students' knowledge, attitudes, and behaviors towards date palms were statistically analyzed across every sub-scale and its items, as well as according to gender and geographical region, using Statistical Packages for Social Sciences (SPSS). 
Table 2. Mean values and standard deviations of Students' knowledge, attitudes and behaviors for each domain

\begin{tabular}{lcccc}
\hline Dimension (Subscales) & Maximum Mean Score & Mean value & Standard Deviation & Percentage (\%) \\
\hline Knowledge about date palms & 1.00 & 0.60 & 0.12 & $60 \%$ \\
Attitudes about date palms & 3.00 & 2.21 & 0.35 & $73 \%$ \\
Behaviors about date palms & 3.00 & 2.07 & 0.53 & $68 \%$ \\
\hline
\end{tabular}

\section{RESULTS AND DISCUSSION}

\section{Research Question One: What are the Knowledge, Attitudes, and Behavior of Grade 10 Students in Omani Schools towards the Palm?}

In order to answer the first research question mean values and the standard deviations for each domain (sub-scale) and their items were calculated (Tables 2- 5).

It is clear from Table 2 that student attitudes towards the date palms obtained the highest average (73\%). Perhaps the reason is due to the interest of the Omani community and the government in the date palm; as His Majesty, the late Sultan stressed its importance as the backbone of food security in the Sultanate (Badawi et el, 2016). Date palm is the main food on the Omani dining table, and it is a symbol of hospitality and generosity, as you rarely find a house without dates (Times of Oman, 2017).

General behaviors about date palms domain resulted in the second-highest mean value of the instrument $(68 \%)$. This is maybe because students practice some of the palm-related work as a result of their presence in most homes, where the palm needs constant care and attention such as fertilizing, watering, harvesting and preserving the transportation of pollen and other work related to the palm. That students' practice, this work leads to improving and developing their agricultural practices, which creates a positive attitude towards them (Ambusaidi, Al-Yahyai, \& Taylor, 2015).

Furthermore, it is noted from Table 2 that the mean values for "Students' knowledge toward date palms" domain is low (Only 60\% performance). Perhaps this is due to the lack of dealing with agriculture in general and date palms in particular in the school curricula (Ambusaidi \& Al-Saidi, 2019). Additionally, students at this age are away from reading about agriculture and rely on their date palms' knowledge from the school curriculum only.

Many options can enhance students' interest in the date palms. The first option is to set up agriculture activities inside or outside the school and encourage students to perform them by, for example, do the watering, fertilizing date palms, following up the pollination, and harvesting process. The second option is to hold student competitions to increase their knowledge about the date palms; by letting, for example, the science teacher at school posts a weekly question about the palm and ask students to answer it then rewards students who answer it correctly. The third option is to allocate marks or prize for extra reading about date palms for those students who do it. The fourth option is to host old people in the morning assembly who have sufficient experience with date palms to give an exciting lecture about date palms and perform activities related to this type of trees, especially the traditional handmade materials from the parts of the date palms. Ideas like these help students gain useful knowledge and develop students' attitudes and motivation towards date palms (Jones, 2012).

Emphasis must also be placed on students' behaviors while dealing with date palms and local trees, as the students' interaction with these trees increases their environmental knowledge and commitment to environmentally responsible behaviors (Hutchinson et al., 2015). Through direct engagement with the palm, the student can acquire behavioral skills such as performing irrigation, and personal skills such as knowledge of healthy foods (Triador, Farmer, Maximova, Willows, \& Kootenay, 2015).

Mean values and standard deviations were calculated for each item in the three sub-scales to give more in-depth results and discussion. We will start with the first domain (sub-scale), which is students' knowledge about date palms.

\section{First: Students' knowledge about date palms}

Table 3 presents the mean values and standard deviations for the first sub-scale which is about students" knowledge of date palms.

It is noticeable from Table 3 , that the mean values of students' knowledge about date palms are high in items $2,1,7$, and 9. Item 2 scored high mean value among the rest of the items in this domain, and this item deals with date palm compositions (i.e., sugar and protein). This is because most of the date palm that are eaten in Omani meals taste sweet, especially the "Alkhalas" type. This type of date palm is very sweet and more delicious than others. The second item in the highest mean value is item number 1, which states, "Dates are considered a complete food." The reason behind this may be students hear from their parents that date palms are essential and contain many elements that the body needs, such as protein and carbohydrates. In addition, this is maybe related to the religious background of students. In the holy book for Muslims (Quran), there is a mention of the date palms, and it is significant in many Quran verses.

The third item with high mean values is item number 7 , which states that "the palm fruit in all seasons of the year." This item highlights the misconception that 
Table 3. Mean values and standard deviations of knowledge about date palms sub- scale

\begin{tabular}{|c|c|c|c|}
\hline No. & Item & Mean & SD \\
\hline 2 & Dates contain sugars and protein & 0.88 & 0.32 \\
\hline 1 & Dates are considered a complete food & 0.87 & 0.33 \\
\hline 7 & The date palm produces fruit all year round & 0.85 & 0.36 \\
\hline 9 & Palm fiber is used in making ropes & 0.84 & 0.36 \\
\hline 5 & Dates contain fat & 0.83 & 0.38 \\
\hline 6 & Palm breeding with seedlings is the primary method for palm propagation & 0.78 & 0.40 \\
\hline 8 & Most palm injuries in the Sultanate of Oman are caused by the palm weevil lesion & 0.76 & 0.43 \\
\hline 4 & Some types of dates cannot be eaten & 0.75 & 0.43 \\
\hline 25 & The number of male palm species is equal to the number of female palm species & 0.74 & 0.44 \\
\hline 23 & "Altabsil" process (cooking dray dates in big bowel) is frequent in Al Dakhiliya Governorate & 0.72 & 0.45 \\
\hline 21 & $\begin{array}{l}\text { "Altabsil" is an Omani customs, which simply means cooking with the secret of the palm (before it } \\
\text { becomes a date) }\end{array}$ & 0.70 & 0.46 \\
\hline 10 & The rug made from palm leaves is called aldaen (Omani cover sheet made from date palms) & 0.69 & 0.47 \\
\hline 17 & The finest types of palm are available in the coastal areas of Oman & 0.64 & 0.48 \\
\hline 12 & Palm oil is extracted from the cores & 0.62 & 0.49 \\
\hline 13 & The number of palm varieties in the Sultanate exceeds 100 species & 0.61 & 0.48 \\
\hline 19 & The palm does not need pruning and trimming like any other plant & 0.56 & 0.49 \\
\hline 18 & Palms need a large amount of water & 0.46 & 0.49 \\
\hline 11 & The palm can be used as a fuel & 0.43 & 0.50 \\
\hline 22 & Often the palm needs many years to start with the first flower (germination) & 0.42 & 0.49 \\
\hline 24 & The Sultanate of Oman ranks first in the world in the number of date palms & 0.37 & 0.48 \\
\hline 15 & The Million Date Palm project aims to cultivate the "alkhalase" cultivar as a basic type & 0.34 & 0.47 \\
\hline 20 & It will not give the palm a wet unless a person transfers pollen to it from another palm & 0.33 & 0.47 \\
\hline 14 & Palm cultivation is common in the Sultanate of Oman in coastal areas & 0.32 & 0.47 \\
\hline 16 & The hot weather is the most suitable environment for planting date palms & 0.14 & 0.35 \\
\hline 3 & Alkhalse and alfredhe are among the most common types of date palms in the Sultanate of Oman & 0.11 & 0.30 \\
\hline
\end{tabular}

students' held about date palms. It is not true that date palms can produce fruits in all seasons, at least in the Omani context. The reason why students held this misconception might be: 1) they mixed between dates when it just starts in the palm and when it completely becomes brown or black at the late stage. 2) These days the dates at different stages can be found in the market due to different ways of maintaining their taste and quality throughout the year and imported from outside. Item " 9 " received a mean value of 0.84 , which is a high mean value. This item is dealing with using palm fiber in making ropes. In Omani culture, these ropes are used for many purposes, including climbing the date palms. They can be seen in many traditional markets and restaurants, so it is easy for students to respond to questions that link date palms with ropes.

The lowest mean values are item number 3 , which states that Alkhalas and Alfardh (names in Arabic for the two types of date palms) are among the most common types of date palms in the Sultanate of Oman. This is not true; in Oman, there are other types of date palms, which are most common in terms of growing area than these two mentioned types. Students may think that these two types are the most common because they are more famous in the Omani dining table. The other item with low mean values is item number 16, which states, "The hot weather is the most suitable environment for planting date palms." Many students get this wrong answer, which indicates that students do not know precisely the suitable weather conditions of planting the trees. However, Oman is located in a dry, hot area, and date palms are the most common fruits grown in Oman. The date palm abounds in the dry climate and high temperatures in the belt of date palms between Latitude 16-27 North of the Equator, in which palm cultivation and date production are found (National Symposium on Agricultural Development Management in the Arab World, 1994). There is a need in the science curriculum to highlight date palms when dealing with agriculture chapters of the textbooks.

\section{Second: Students' Attitudes about date palms}

Table 4 presents the mean values and standard deviations for the second sub-scale students' attitudes about date palms.

It is noticed from Table 4 that the mean values of students' attitudes toward the palm, in general, in most items are high $(2,1,7,12,4,11,5,6,9)$. The first item with high mean value is item number 2 , which states: "I support the government in its interest in the date palm and supporting farmers." This value indicates the importance of date palms in Omani society including food security (Ambusaidi \& Almakbaliya, 2019). Oman is traditionally an agricultural society where many Omanis in the past were working in this sector. Omani farmers believe strongly that the date palm is a symbol of the Omani character and a source of pride for it. Therefore, item number 1, "The date palm was considered a symbol of the Omani man," scored the second-highest mean values in this domain. This attitude is supported by students' responses in items 
Table 4. Mean values and standard deviations of the attitudes about date palms

\begin{tabular}{|c|c|c|c|}
\hline No. & Item & Mean & $\mathrm{SD}$ \\
\hline 1 & I support the government in its interest in the palm tree and supporting farmers & 2.64 & 0.62 \\
\hline 2 & The date palm was considered a symbol of the Omani man & 2.63 & 0.62 \\
\hline 7 & I like to eat dates that I contribute in its harvest & 2.57 & 0.71 \\
\hline 12 & The date palm makes me proud. & 2.54 & 0.69 \\
\hline 4 & I encourage my peers to have an interest in the date palm. & 2.45 & 0.72 \\
\hline 11 & I would like to see the Omani curriculum highlights the date palm. & 2.34 & 0.77 \\
\hline 5 & I can count on the date palm as a source of future income & 2.32 & 0.77 \\
\hline 6 & I do not like to pick date palms because they make me feel tired. & 2.22 & 0.78 \\
\hline 9 & I make an opinion on the date palm cultivation site & 2.21 & 0.77 \\
\hline 8 & I recommend cutting off the oldest palm & 1.93 & 0.78 \\
\hline 3 & $\begin{array}{l}\text { I hope to study at the College of Agriculture and Marine Sciences in Sultan Qaboos University to } \\
\text { learn more about the date palm. }\end{array}$ & 1.77 & 0.78 \\
\hline 10 & The palm takes a large part of my time without interest & 1.61 & 0.80 \\
\hline 13 & I hope to work at the Agricultural Research Center when I grow up & 1.60 & 0.74 \\
\hline
\end{tabular}

Table 5. Mean values and standard deviations of the behavior sub scale items about date palms

\begin{tabular}{|c|c|c|c|}
\hline No. & Item & Mean & $\mathrm{SD}$ \\
\hline 5 & I participate in harvesting and keeping the dates & 2.45 & 0.78 \\
\hline 1 & I can distinguish the date palm by watching the fruit (linkage). & 2.41 & 1.16 \\
\hline 6 & I water the date palms periodically & 2.23 & 0.80 \\
\hline 4 & I remove weeds around the palm & 2.21 & 0.85 \\
\hline 2 & I help my parent in planting date palms & 2.19 & 1.31 \\
\hline 8 & I help my father in trimming the palm and removing dry fronds & 2.03 & 0.87 \\
\hline 3 & I constantly fertilize the palm & 2.01 & 1.63 \\
\hline 7 & I can germinate (transfer pollen) & 1.96 & 0.88 \\
\hline 11 & I read a lot of articles to find out more about the date palm & 1.90 & 0.77 \\
\hline 10 & I spend part of my summer vacation looking after the date palms & 1.72 & 0.78 \\
\hline 9 & $\begin{array}{l}\text { I make sure to visit the date festival, which is organized annually by the Ministry of Agriculture } \\
\text { and Fishers }\end{array}$ & 1.71 & 0.77 \\
\hline
\end{tabular}

numbers 7,12 , and 4 . This also reflected by the fact that the Omani government recently invest more focus on date palms sector through running several projects and enterprises, including the "Million Date palms Project." It is one of the pioneering projects in the Sultanate, with economic, social, and environmental returns it will generate. A qualitative shift is expected to take place in the date palm sector by applying the latest scientific developments in agricultural operations and the manufacture of dates. This will enhance the ability of Omani date palms to compete in foreign markets. In this project, a governmental company dealing with date palms was established. The company is going to build several factories to produce several products extracted from palm dates and from natural juices i.e. energy drinks, healthy drinks and drinks for children as well as some products such as dough and products from concentrated dates syrup, like dessert dates and date butter. In addition, the secondary products of palm waste such as natural charcoal, palm wood panels and fertilizer feeds and others (Al Zajali, 2018).

Regarding the education part, students wish the Omani curricula pay more attention to and interest in the date palms. This is highlighted in students' responses to item number 11 . If such positive trends towards the date palms occur, then this should be emphasized through preparing an appropriate agricultural educational environment and activities such as the school garden
(Ambusaidi et al., 2018), in which date palm is cultivated and taken care of by students to reinforce positive trends.

It is noted from the table that the items 10 and 13 obtained the lowest mean values. In item 10 , it seems that students have negative attitudes towards studying the agricultural field. This item shows students' reluctance to join the College of Agriculture or work at the Agricultural Research Center. Perhaps the reason is due to the students' inclination towards work that does not require much effort or their preference for jobs that use technology and engineering. The second item with low mean value is item 13, which may indicate students less interest to do activities related to date palms. There is a need, as Osborne, Simon, and Collins (2003) state, to develop students' positive attitudes towards agriculture in general and the cultivation of local trees and paying particular attention to them.

\section{Third: Students' behaviors about date palms}

Table 5 shows the mean values and standard deviations for the second sub-scale students' behaviors about date palms.

From Table 5, it can be seen that 6 out of 11 items in this domain or sub-scale scored a mean value higher than 2.00, which shows that there are some behaviors that students are doing or willing to do related to date 
Table 6. Mean values and standard deviations of students' knowledge, behavior and attitudes differ according to gender, geographical regions

\begin{tabular}{lcccccccc} 
Dimension & \multicolumn{4}{c}{ Gender } & \multicolumn{3}{c}{ Geographical Region } \\
\cline { 2 - 10 } & \multicolumn{2}{c}{ Male } & \multicolumn{2}{c}{ Female } & \multicolumn{2}{c}{ Al-Dakhiliyah } & Muscat \\
\cline { 2 - 9 } & M & SD & M & SD & M & SD & M & SD \\
\hline Knowledge about date palms & 0.60 & 0.12 & 0.59 & 0.11 & 0.61 & 0.10 & 0.59 & 0.13 \\
Attitudes about date palms & 2.26 & 0.35 & 2.13 & 0.34 & 2.28 & 0.31 & 2.11 & 0.37 \\
Behaviors about date palms & 2.31 & 0.43 & 1.83 & 0.51 & 2.11 & 0.51 & 2.02 & 0.54 \\
\hline
\end{tabular}

palms. For example, they participate in the harvesting and keeping dates, they water date palms periodically, and they remove weeds around the palm. The reason for this is the existence of date palms in most of the Omani houses and the main roads and public gardens. Distinctly, the students who are living in rural areas (outside the capital and big cities) are very close to date palms and dealing with it in their daily life directly or indirectly with their parents.

However, although this is the case, some students are not willing to read a lot of articles to find out more about the palm (item number 24) or visit the date festival, which is organized annually by the Ministry of Agriculture and Fishers (item number 9). The reason for the former is that students nowadays like technological and electronic devices and are thus less motivated for reading and not only in the area of agriculture but in many areas. And if they read, they read novels and stories, not scientific topics. To encourage students to read about agriculture in general and in date palms in particular, schools can adopt a reading competition or can enrich the subjects (science and social studies) with simple booklets and brochures about the date palms.

Reading helps achieve the goals of learning science, as it contributes to the development of the knowledge structure, the development of the individual's information and linguistic outcomes, and the cognitive independence of the learner and contributes to the development of emotional aspects (Ambusaidi \& AlBalushi, 2011). All these may lead to increasing students' knowledge and interest in date palms.

For the later statements, the reason for not visiting the festival related to date palms maybe because it is not among their interest or perhaps this festival is a classical festival, and there are less attractive activities in it. Additionally, the festival was recently held in Muscat (the capital of Oman), which is far away for students in other governorates. Therefore, it was suggested to establish the date festival in all regions so that all students can attend or participate in it. Besides, the organizer of this festival should think out of the box by introducing creative activities, including electronic activities, which are more attractive to students than activities that require physical activity. Balasubramaniam and Indhu (2016) assert that students' reluctance to participate in these physical activities may be due to students' preoccupation with the mobile phone and its applications. The high use of electronic communication sites and electronic games, and the continuous development of automated programs attract students' attention consistently.

Despite that, students may learn about date palms through electronic activities. There is still though a need for real physical learning experiences such as planting date palms or other trees and caring for them outside the classroom. These activities allow the learner to go through learning experiences that are difficult to pass within the classroom (Ghazi, 2000) and promote critical thinking, practical training, and cooperative learning (Davidson, 2014). Both educators and parents should work together to provide the opportunities to students to practice agricultural skills such as planting seedlings, watering, fertilizing, and transporting pollen, in order to change the behaviors of students about date palms, which of course will affect students" knowledge and attitudes.

\section{Research Question Two: Do these Knowledge, Attitudes and Behaviors Differ According to Gender, Geographical Regions, and Interaction between these Two Variables?}

The mean values and standard deviations of student responses in the threes sub-scales were calculated to find out if their knowledge, behavior, and attitudes differ according to gender, geographical regions (Table 6).

From Table 6, it can be seen that male and female students' responses are the same in knowledge about date palms sub-scale. However, for other two domains (attitudes about date palms and behavior about date palms), male student responses had higher mean values than female students. Regarding the geographical region, student responses in Al-Dakhiliyah Governorate had higher mean values in all three domains compared to students from Muscat Governorate. In order to determine whether these differences, were statistically significant, a multivariate analysis was used (Table 7).

There were statistically significant differences in the students' knowledge, attitudes and behaviors towards date palms (Table 7) related to students' gender and geographical regions and the interaction between them. However, to identify the direction of these differences, the second step of multivariate analysis (determining the domains of students' knowledge, attitudes and behaviors towards date palms, which had functional impacts) was calculated in Table 8. 
Table 7. Results of multivariate tests

\begin{tabular}{|c|c|c|c|c|c|}
\hline Source of variance & Wilks' Lambda & $\mathrm{F}$ & Hypothesis df & Error df & Sig. \\
\hline Gender & 0.779 & 91.04 & 3.000 & 883.000 & 0.001 \\
\hline Geographical Region & 0.932 & 23.482 & 3.000 & 883.000 & 0.001 \\
\hline Gender $\times$ Geographical Region & 0.986 & 4.527 & 3.000 & 883.000 & 0.040 \\
\hline
\end{tabular}

Table 8. Test of Between -Subjects effect

\begin{tabular}{|c|c|c|c|c|c|c|}
\hline Source of variance & Dimension of attitudes & Type III Sum of squares & $\mathrm{df}$ & Mean square & $\mathrm{F}$ & Sig. \\
\hline \multirow[t]{3}{*}{ Gender } & Knowledge about date palms & .007 & 1 & 0.007 & 0.500 & 0.480 \\
\hline & Attitudes towards date palm & 4.043 & 1 & 4.043 & 36.65 & 0.001 \\
\hline & Behaviors towards date palms & 56.737 & 1 & 56.737 & 263.085 & 0.001 \\
\hline Geographical & Knowledge about date palms & .079 & 1 & .079 & 6.012 & 0.014 \\
\hline \multirow[t]{2}{*}{ Region } & Attitudes towards date palms & 7.376 & 1 & 7.376 & 66.869 & 0.001 \\
\hline & Behaviors towards date palms & 5.728 & 1 & 5.728 & 26.562 & 0.001 \\
\hline Gender $\times$ & Knowledge about date palms & .024 & 1 & .024 & 1.798 & 0.180 \\
\hline Geographical & Attitudes towards date palms & .266 & 1 & .266 & 2.408 & 0.121 \\
\hline Region & Behaviors towards date palms & 2.399 & 1 & 2.399 & 11.125 & 0.001 \\
\hline \multirow[t]{3}{*}{ Error } & Knowledge about date palms & 12.625 & 890 & .013 & & \\
\hline & Attitudes towards date palms & 106.440 & 890 & .110 & & \\
\hline & Behaviors towards date palms & 208.112 & 890 & .216 & & \\
\hline
\end{tabular}

Table 8 demonstrates that there are statistically significant differences in the domains of attitudes and behaviors towards date palms for the gender variable. It also shows statistically significant differences in all domains in the geographical region. In addition, from Table 8, it is shown that there are statistically significant differences in behaviors towards date palms only in the interaction between gender and geographical region. In reference to Table 6, male students' mean values are higher than female students' mean values in the attitudes and behaviors towards date palms sub-scales. This is maybe due to the fact that, regionally, agriculture has typically been a more male-oriented and maledominated activity, often-requiring intense physical effort. In addition, when working on a farm or house garden, both culturally and traditionally, Omani male students typically hold a closer relationship with their fathers compared to female students. Halpern et al. (2008) assert that males are more distinguished in work skills that require accuracy and physical exertion than females.

For the knowledge about date palms domain, male and female students' responses are the same, and this is maybe to the lack of adequate access to external references and readings on the date palm, and the lack of inclusion of such subjects in the school curricula, whether in science or social studies. Halpern et al. (2008) assert that students tend to score lower scores in cognitive tests when the content does not directly relate to what is taught in their curriculum.

The results in Table 6 show that students in the AlDakhiliyah region scored higher mean values in all three domains (sub-scales) compared to students from Muscat region. This is maybe due to the rural environment that characterizes Al-Dakhiliyah region and the wider areas of farms and farm lands. Most homes in this region are characterized by the presence of a date palm farm surrounding the house, and this is reflected in the students' knowledge, attitudes, and behaviors towards date palms in this region. The Ambusaidi and Al-Saidi (2019) study confirmed that students who live in agriculturally oriented areas, such as the Al Dakhiliya region (Governorate), have more positive attitudes towards agriculture than students who live in the urban areas (Governorate of Muscat).

The results in Table 6 show that male students in the Al Dakhiliya region (Governorate) are more interested in date palms, and this is maybe due to the nature of this region, and agriculture is usually male-oriented. Muscat is a coastal region where people are more interested in fishing and diving than farming. While Al Dakhiliya region is characterized by being a region that contains fertile soil and an abundant amount of water, so most of its population works in agriculture, where palm is cultivated significantly. In this region, almost all houses have a garden or mini-farm that containing date palms. Taking care of the farm is one of the male duties because of the male physical build that enables them to harvest the date palms and carry out the pollination process, and store the harvest for long periods.

Another reason for higher interest in date palms among students from the interior region is the fact that Muscat region is the capital of Oman and students find many entertainment programs and places to visit and spend their free time, such as beaches and commercial centers. But this is not the case for Al Dakhiliya region where less entertainment options are found so students spend more time tending to their trees and farms in general. 
Table 9. Mean values, standard deviations and $t$-values of the presence of date palms in the house

\begin{tabular}{lcccccc}
\hline Domain (Sub-scale) & Yes / No & N & Mean & SD & t & Sig. \\
\hline Knowledge about date palms & Yes & 220 & 0.58 & 0.09 & 0.926 & 0.355 \\
& No & 220 & 0.59 & 0.15 & & \\
\hline Attitudes towards date palms & Yes & 220 & 2.17 & 0.342 & 3.392 & 0.001 \\
& No & 220 & 2.06 & 0.380 & 0.490 & 4.656 \\
\hline Behavior towards date palms & Yes & 220 & 2.10 & 0.552 & & 0.001 \\
& No & 220 & 1.88 & & \\
\hline
\end{tabular}

Table 10. Mean values, standard deviations and $t$-values of when a family member works in the agriculture sector

\begin{tabular}{lcccccc}
\hline Domain (Sub-scale) & Yes / No & $\mathrm{N}$ & Mean & Std. Deviation & $t$-value & Sig \\
\hline Knowledge about date palms & Yes & 443 & 0.60 & 0.13 & 2.079 & 0.021 \\
& No & 451 & 0.50 & 0.10 & & \\
\hline Attitudes towards date palms & Yes & 443 & 2.27 & 0.33 & 0.823 & \\
& No & 451 & 2.13 & 0.35 & 0.50 & 6.425 \\
\hline Behavior towards date palms & Yes & 443 & 2.18 & 0.54 & & \\
& No & 451 & 1.97 & & \\
\hline
\end{tabular}

\section{Research Question Three: Do Students' Knowledge, Attitudes, and Behaviors towards Date Palms Differ if there are Date Palms in their Houses or not?}

The mean values, standard deviations, and $t$-values of students' responses in each domain (sub-scale) were used to find out if their knowledge, attitudes and behaviors differ in light of the presence of date palms in their houses (Table 9).

It can be seen from Table 9, that there are no statistically significant differences in students' knowledge about date palms whether the date palm is present at home or not. This is maybe due to the lack of any knowledge about date palms in the school curriculum so that students can gain information about them, which than emphasize from existing date palms at home. Moreover, it is possible that students do not have interest in reading about date palms, as mentioned earlier, as most students at this age prefer reading novels or watching soccer games.

However, the results in Table 9 show that there are statistically significant differences in both students' attitudes and behaviors domains in favor of students who own date palms in their homes. This is maybe due to their sense of responsibility and interest in helping their parents. The presence of date palms in the house generally means the availability of dates daily at the dining table, which develops the inner feeling and motivation among individuals towards the date palm, and becomes indispensable part of their daily life. The learning environment in the home garden or farm helps to develop natural intelligence, adhere to environmentally responsible behaviors (Hutchinson et al., 2015), and develop environmental sustainability practices such as water and energy conservation, waste reduction, and creating a healthy environment (Williams \& Lee, 2009). Perpinal (2015) indicates that planting in the home garden and owning local trees such as date palms leads to several benefits, including:
- The educational aspect: allows learning about the nature and food that students eat and makes them appreciate the value of their effort in growing crops.

- The health aspect: students eat healthy vegetables on a daily basis that enhances physical health because they contain important elements. In addition, it makes students incorporate these vegetables permanently into their meals and stay away from vegetables that have been genetically modified or sprayed with pesticides. Also, working in the garden allows for moderate physical activity and contributes to maintaining fitness.

- Sustainability aspect: it contributes to increasing students' awareness of the importance of food, preventing waste, and throwing excess of it into the garbage. The planting of trees also generates a sense of appreciation and ownership of the fruits in their dishes, so it is difficult to waste.

- Social aspect: working in agriculture with family and neighbors provides an opportunity for joint action, acquaintance and assistance, a sense of responsibility, and societal pride.

\section{Research Question Four: Do Students' Knowledge, Attitudes and Behaviors towards Date Palms Differ if Somebody in their Families Works in an Agriculture Sector?}

The mean values, standard deviations and $t$-values of student responses for each sub-scale were calculated to find out if their knowledge, attitudes and behaviors differ if family member works in the agriculture sector (Table 10).

From Table 10, it is observed that there are statistically significant differences in students' knowledge, attitudes and behaviors when a family member works in the agriculture sector in favor of those students who have a family member working in this 
field. This is maybe due to the feeling the individual who is working in the agriculture sector has about the importance of date palms makes the rest of the family feel the same about it and, therefore, their attitudes and behaviors become more positive. Moreover, an individual who works in the agricultural field may create a home garden in which he cultivates various varieties of date palms and applies his agricultural experience with family members. When a family member works in the agricultural field, it will force the relative student to understand the agricultural foundations related to date palms, such as watering, fertilizing, growing, harvesting, processing, and other tasks. This allows students to learn and contribute to utilizing their learned skills in the farming process. (Perpinal, 2015). Jones (2012) argued that learning outside the classroom is conducive to a better academic achievement, as it increases students' motivation towards learning. The application of what has been learned in the real world leads to the promotion of scientific thinking and creativity. This practice-based learning has several characteristics, including lifelong learning that integrates work life, a method of understanding an individual and his environmental goals !!! (Tal, Alon, \& Morag,2014).

\section{CONCLUSION AND RECOMMENDATIONS}

The current study found that overall, 10th-grade students in Oman have positive attitudes and behaviors that generally represent date palms, while they have low scientific knowledge about date palms. In addition, male students showed more attitudes and behaviors towards date palms than female students did. This response is somehow a good indication that male students, especially with more support and encouragement, may choose to study agricultural science in higher education or choose to work in fields related to agriculture. In support of this assertion, Greenwald (1989) reported that people with positive attitudes towards a situation or subject tend to support them positively. In Oman, there is a need for more Omani workers in the agriculture sector to replace the low-skilled expatriate' workers and to maximize food security.

The results of the current study revealed that students in Al Dakhiliyah Governorate demonstrate more behaviors and attitudes towards date palms than their peers in Muscat Governorate. This is maybe that students in Muscat Governorate are less likely to have exposure to agricultural activities because they are in more urban areas (Ambusaidi \& Al-Saidi, 2019). Moreover, the current study showed that the students have positive attitudes and behaviors toward the date palms by the availability of the date palms on their houses or the presence of a family member working in the agricultural field; however they did not gain any additional knowledge.

Based on the results of this study, there is a need to develop a strategic plan to generate more interest in date palms among school students across the Sultanate. This project can be designed and managed by the Ministry of Education, the Ministry of Agriculture and Fisheries, and the Royal Court's office responsible for the "One Million Date Palms Project." In fact, in the study, both genders showed positive attitudes and behaviors towards the date palms, but there is a lack of knowledge with both genders about date palms, and needless to say that scientific knowledge is the vehicle for development. Therefore, the introduction of such knowledge in the school curricula such as science or social studies curricula and dedicating of part of the school garden for palm cultivation will have a major impact on developing students' knowledge, behaviors, and attitudes towards the date palms (Ambusaidi, Al-Yahyai, \& Taylor, 2015).

Furthermore, the Ministry of Education can initiate a "Green School Initiative" across all schools in the country, with all students participating. Such an initiative is strongly linked to sustainable development in the community (Ambusaidi, 2018). Many activities can be conducted in schools related to such an initiative, including planting the date palms within the school area. This type of initiative goes beyond improving students' knowledge, attitudes, and behaviors towards the date palms by encouraging students to be more eco-friendly both at home and at school (Li \& Lang, 2014).

The current research is just the beginning for more exploration of the agricultural education in Oman. There are some limitations of this study such as it targets students in only two geographical regions in Oman. Therefore, more researches are needed by targeting more students in different geographical regions in Oman. Moreover, the current study used a quantitativebased questionnaire (scale) in the form of a Likert scale to collect data. However, using a qualitative approach in future studies, such as focus groups, would provide indepth data about students' knowledge, attitudes, and behaviors toward date palms. In addition, a quasiexperimental design can be used also to study, for example, the effect of teaching methods or training programs on students' knowledge, attitudes, and behaviors towards the date palms, which may reveal the cultural and societal effects of agriculture. Osborne et al. (2003) noticed that it was behavior rather than attitude that became a focus of interest in studying the attitudes of students.

Further studies are needed to explore higher education students' knowledge, attitudes, and behaviors towards the date palms. This can be associated with respondents' socio-economic and demographic variables. Also, it can be done through comparing the knowledge, attitudes, and behaviors of farming 
community children with non-farming community students. Another study aspect is to investigate the role of teachers in schools who teach subjects related to agriculture such as science and social studies.

Finally, this study aims at sharing knowledge with other researchers about Omani students' knowledge, attitudes, and behaviors towards the date palms. Researchers with interest in agricultural education may adopt this study's instrument to explore additional dimensions of students' knowledge, attitudes, and behaviors, or other types of participant groups. Globally, the results of this study can be used to compare Omani students' knowledge, attitudes, and behaviors towards the date palms with students of similar age in other countries to examine similarities and differences, as well as social and cultural influences.

\section{REFERENCES}

Al Zajali, A. (2018). Today .. the establishment of a development company, Nakhil Oman. AL Shabiba Newspaper. Retrieved on 4 April 2020 from https://www.shabiba.com/article/217274 (In Arabic).

Al-Hamiri, A., \& Al-Badri, A. St. (2001). The desire of students of the Faculty of Agriculture to work in agriculture. Arts Magazine - Baghdad, No. 56, 418403. (In Arabic). Retrieved from https://search.mandumah.com/Record/664802

Al-Hashemi, S. M. (2003). The Place of the Palm in Oman's Heritage and Its Most Important Products, Popular Mathurat Magazine- Doha, 68. Retrieved from http:/ / alwatan.com/ details/16385

Al-Majrafi, N. (2019). Cultivation of palm seedlings in schools and calling them the names of students. Oman Pulse. Retrieved on 16 April 2020 from http://nabdoman.om/5725/

Ambusaidi, A. (2018). Towards a Comprehensive School Sustainability: Practical Examples from Arab Gulf Countries. Doha, UNESCO Office. (In Arabic). Retrieved from https://search.mandumah.com/ Record/90148

Ambusaidi, A., \& AL- Balushi, S. (2011). Science Teaching Methods: Concepts and Practical Applications. Amman, Dar Al-Masirah for Publishing, Printing and Distrbutions. (In Arabic).

Ambusaidi, A., \& Al-Alwi, K. (2019). The effectiveness of employing the school garden in achieving academic achievement and the perceptions of the seventh grade students towards agriculture. Journal of Educational and Human Sciences, 20(20), 243-269. (In Arabic). https://doi.org/10.12785/JEPS/ 200208

Ambusaidi, A., \& Almakbaliya, F. (2019). Awareness level of grade eleven students in Oman about food security in relation to some variables. Journal of
Educational Sciences, (20), 137-154. (In Arabic). https:// doi.org/10.29117/jes.2019.0013

Ambusaidi, A., \& Al-Saidi, M. (2019). Omani School Students' Attitudes toward Agriculture: Investigating the Role of Gender and Geographical Regions. Journal of Educational \& Psychological Studies, 13(4), 733-748. https://doi.org/10.24200/ jeps.vol13iss4pp733-748

Ambusaidi, A., Al- Yahyai, R., \& Taylor, N. (2015). Establishing and researching school gardens in Oman as a resource for improving education outcomes. Environment and Economic Studies, 15(4), 415-430. Retrieved from http://ezproxysrv.squ. edu.om:2071/login.aspx?direct $=$ true $\& \mathrm{db}=\mathrm{edb} \& \mathrm{~A}$ $\mathrm{N}=135385010 \&$ site $=$ eds-live\&scope $=$ site

Ambusaidi, A., Al-Yahyai, R., Taylor, S., \& Taylor, N. (2018). Introducing School Gardens to the Omani Context: A preliminary study with Grade 7 classes. Eurasia Journal of Science, Mathematics and Technological Education, 14(3), 1043-1055. https:/ / doi.org/10.12973/ejmste/80859

Astin, A. W. (1993). What Matters in College (Vol. 9). San Francisco, Jossey-bass.

Badawi, S., Abdul Ghani, S, Khalil, K., \& Abdul Hamid, M. (2016). The effectiveness of a proposed in the home economy for the development of nutritional awareness among students in the preparatory stage in North Sinai. Journal of Reading and Knowledge, 120, 51-67 (In Arabic).

Balasubramaniam, G., \& Indhu, K. (2016). A Study of Learning Style Preferences among First Year Undergraduate Medical Students Using VARK Model. Education in Medicine Journal, 8(4), 15-21. https:// doi.org/10.5959/ eimj.v8i4.440

Bowker, R., \& Tearle, P. (2007). Gardening as a learning environment: A study of children's perceptions and understanding of school gardens as part of an international project. Learning Environ Res, 10, 83100. https:/ / doi.org/10.1007/s10984-007-9025-0

Christian, M., Evans, C., Conner, M., Ransley, J., \& Cade, J. (2012). Study protocol: can a school gardening intervention improve children's diets?. BMC Public Health, 12. https://doi.org/10.1186/1471-2458-12304

Cohen, L., Manion, L., \& Morrison, K. (2000). Action research. Research methods in education, 5, 226244.

Davidson, R. (2014). Using infographics in the science classroom. The Science Teacher, 81, 34-39. https://doi.org/10.2505/4/tst14_081_03_34

Ghazi, I. T. M. (2000). The cultural, knowledge and sentimental contents in the context of the text of the scientific trip reports. Studies in Curricula and Teaching Methods - Egypt, p. 62, 1-48. (In Arabic). 
Retrieved from https://ezproxysrv.squ.edu.om: 2228/Record/40465

Greenwald, A. G. (1989). Attitude Structure and Function. Hillsdale, NJ: Erlbaum Associates.

Halpern, D. F., Benbow, C. P., Geary, D. C., Gur, R. C., Hyde, J. S., \& Gernsbacher, M. A. (2008). The science of sex differences in science and mathematics. Psychological Science in The Public Interest, 8(1), 1-51. https://doi.org/10.1111/j.15291006.2007.00032.x

Heim, S., Stang, J., \& Ireland, M. (2009). A garden pilot project enhances fruit and vegetable consumption among children. Journal of the American Dietetic Association, 109(7), 1220-1226. https://doi.org/ 10.1016/j.jada.2009.04.009

Hoffman, A. J., Trepagnier, B., Cruz, A., \& Thompson, D. (2004). Gardening activity as an effective measure in improving self-efficacy and self-esteem: Community college students learning effective living skills. The Community College Enterprise, 9, 231-239.

Hutchinson, J., Christian, M. S., Evans, C. L., Nykjaer, C., Hancock, N., \& Cade, J. E. (2015). Research report: evaluation of the impact of school gardening interventions on children's knowledge of and attitudes towards fruit and vegetables. A cluster randomized controlled trial. Appetite, 91405-414. https://doi.org/10.1016/j.appet.2015.04.076

Ibrahim, K. M. (2010). The role of date palm tree in improvement of the environment. Acta Hortic., 882, 777-778. https://doi.org/10.17660/ ActaHortic. 2010.882.87

Jones, R. A. (2012). What were they thinking? Instructional strategies that encourage critical thinking. The Science Teacher, 79(3), 66-70. Retrieved from http://ezproxysrv.squ.edu.om:2071/login. aspx?direct $=$ true \&db=edsggo\&AN=edsgcl.295060 $744 \&$ site $=$ eds-live \&scope $=$ site

Li, W., \& Lang, G. (2014). Effects of Green School and Parents on Children's Perceptions of HumanNature Relationships in China. Child Indicators Research, 8, 587-604. https://doi.org/10.1007/ s12187-014-9265-3

Meischen, D. L., \& Trexler, C. J. (2003). Rural elementary students' understanding of science and agricultural education benchmarks related to meat and livestock. Journal of Agricultural Education, 44(1), 4355. https:/ / doi.org/10.5032/jae.2003.01043

Metin, M., Acisli, S., \& Kolomuc, A. (2012). Attitude of elementary prospective teachers towards science teaching. Procedia- Social and Behavioral Sciences, 46, 2004-2008. https://doi.org/10.1016/j.sbspro.2012. 05.418

Ministry of Agriculture and Fisheries (2020). National strategy. Retrieved from https://www.maf.gov.om
National Centre for Statistics and Information (NCSI) (2018). Share of Agriculture Sector in GDP (\%). Retrieved from http://Www.ncsi.gov.om (In Arabic).

National Symposium of the Department of Agricultural Development in the Arab world. Prepared by the Arab Organization for Agricultural Development. (1994). Arab Organization for Agricultural Development. (In Arabic).

Ohly, H., Gentry, S., Wigglesworth, R., Bethel, A., Lovell, R., \& Garside, R. (2016). A systematic review of the health and well-being impacts of school gardening: synthesis of quantitative and qualitative evidence. BMC Public Health, 16(1), 286. https:/ / doi.org/10.1186/s12889-016-2941-0

Osborne, J., Simon, S., \& Collins, S. (2003). Attitudes towards science: A review of the literature and its implications. International journal of science education, 25(9), 1049-1079. https://doi.org/ 10.1080/0950069032000032199

Passy, R., Morris, M., \& Reed, F. (2011). Impact of school gardening on learning: final report to the Royal Horticultural Society. London, National Foundation for Educational Research. https:/ / doi.org/10.1080/03004279.2011.636371

Perpinal M. (2015). Growing vegetables in the home and community garden. ITIC Forum, ALqudas Community Gardens. Retrieved on 4 April 2020 from http://www.sviva.gov.il/Arabic/Subjects Env/EducationAndEnv/Documents / Community Garden.pdf

Sheffield, B. K. (1992). The affective and cognitive effects of an interdisciplinary garden-based curriculum on underachieving elementary students (Unpublished doctoral dissertation), University of South Carolina, Columbia, SC.

Tal, T., Alon, N., \& Morag, O. (2014). Exemplary practices in field trips to natural environments. Journal of Research in Science Teaching, 51(4), 430-461. https://doi.org/10.1002/tea.21137

Times of Oman (2017). Oman second most food-secured country in GCC. 29th November.

Triador, L., Farmer, A., Maximova, K., Willows, N., \& Kootenay, J. (2015). Research Brief: A School Gardening and Healthy Snack Program Increased Aboriginal First Nations Children's Preferences Toward Vegetables and Fruit. Journal of Nutrition Education and Behavior, 47176-180. https:/ / doi.org/10.1016/j.jneb.2014.09.002

Ugras, M., Altunbas, S., Ay, K., \& Cil, E. (2012). Determination of pre-service science and classroom teachers' attitudes towards science teaching and technology and relationship between these attitudes. Procedia- Social and Behavioral Sciences, 47, 
1549-1553. https:// doi.org/10.1016/j.sbspro.2012. 06.859

Wang, J. (2007). Students' Thinking and Alternative Conceptions of Transport Systems in Plants: A Follow-up Study .International Journal of Science \& Math Education, (2), 307. https://doi.org/ $10.1007 /$ s10763-006-9038-7

Williams, D. R., \& Dixon, P. S. (2013). Impact of gardenbased learning on academic outcomes in schools:
Synthesis of research between 1990 and 2010. Review of Educational Research, 83(2), 211-235. https:// doi.org/10.3102/0034654313475824

Williams, M., \& Lee, J. C. (2009). Schooling for Sustainable Development in Chinese Communities. [electronic resource]: Experience with Younger Children. Dordrecht: Springer Netherlands .https://doi.org /10.1007/978-1-4020-9686-0

\section{http://www.ejmste.com}

